\title{
AndRew R. Dyck (ed.), Cicero. Catilinarians, Cambridge: Cambridge University Press, 2008, pp. 282, ISBN 978-0-521-54043-8.
}

With the recent publication of his own Catilinarians, Andrew R. Dyck (hereafter D.) had the opportunity to produce a text which improves upon those of his predecessors, namely Maslowski's 2003 Teubner edition (M. Tullius Cicero, Fasc. 17: Orationes in L. Catilinam quattuor. Bibliotheca Teubneriana. Munich Leipzig: K.G. Saur, 2003). D.'s text, a commentary in the Cambridge series, provides an excellent resource for the four speeches against Catiline. He includes a standard preface complete with maps and a chronological table of events leading up to and surrounding Catiline's conspiracy. Thereafter follows an invaluable introduction which provides a detailed explanation of Catiline's career and the background of the conspiracy.

D. then discusses the speeches themselves as well as their publication, possible revisions, and later tradition. This treatment of how Cicero's speeches were subsequently read and studied places the modern student into the long scholarly tradition dealing with the Catilinarians. Dyck follows with a brief discussion of Cicero's language and style. The introduction is completed by a summation of the manuscript tradition. D. concludes his synopsis with a chart that depicts the main differences between his own text and that of his predecessor, Maslowski (hereafter, M.). And herein lies the crux of D.'s aim: to improve upon that which was done only 5 years prior.

Following are sample sections of D.'s review of M.'s text in order to demonstrate his methodology (as it appeared in the Bryn Mawr Classical Review 2004.04.31). In each of the points below, D. sought to "illustrate M.'s editorial technique." Through a careful reading of his text, I have found that D.'s text incorporates the suggestions, affirmations, and/or disagreements highlighted in his review within his own commentary, which makes up the bulk of the text. These instances provide a window into D.'s sensible handling of some difficult textual questions.

2.3: After defenderent the following is with minor variants transmitted: quam multos qui propter stultitiam non putarent, quam multos qui propter improbitatem faverent? But qui non putarent can in this context hardly be different from qui ... non crederent; and the etiam of qui etiam defenderent suggests that this is the climactic item; if they are authentic, the words quam multos qui propter improbitatem faverent should be transposed to follow crederent: then there would be a logical sequence from believing to supporting to defending. But perhaps quam multos qui propter stultitiam ... faverent has been added by a reader keen to restore the qualities of stultitia and improbitas (cf. 1.30). Moreover, one doubts that Cicero would have spoken so candidly before the populus about the flaws of the senators; hence these words are, in spite 
of rhythmical considerations adduced by T. Zielinski (Das Clauselgesetz in Ciceros Reden, Leipzig 1904, 202), to be deleted with Madvig.

D.'s text includes the quam multos qui propter improbitatem faverent.

2.19: M. sets in the text his own maxima in multitudine, and this seems to be the best conjecture so far offered. It effects a minimally invasive restoration of three points that should make the conspirators doubt of their eventual success: the spirit of the boni, the widespread concordia, and the large number of troops available; it also provides a convincing explanation of the corruption, in being misread as $m$ with concomitant change of the following multitudine to accusative for concord.

D.'s text utilizes the suggestion made by $\mathrm{M}$.

3.16: neque manus neque lingua deerat, though attested only in ah, constitutes a rhythmic clausula and thus deserves preference to the unrhythmical neque lingua neque manus deerat (Schol Gron. CAV beta, gamma) adopted by $\mathrm{M}$.

D. does not diverge from M. here, yet his note demonstrates the two versions and their origins.

3.22: M. retains the dangling nominative illa Allobrogum sollicitatio, iam, deleted by Mommsen and variously emended by editors. But in spite of the defense by P. Ercole ("Ancora di un passo dubbio nella III Catilinaria [IX.22]," RFIC 21, 1893, 139-40), cited by M., one expects an exclamation in accusative, not nominative (cf. R. Kühner - C. Stegmann, Ausführliche Grammatik der lateinischen Sprache. With corrections to the 4th ed. by A. Thierfelder, Darmstadt, 1966, I, 272-3).

D., following Mommsen et alii, does not include the "dangling nominative."

3.26: M. prefers postulabo (alpha, 1, gamma) to postulo ( $\mathrm{sbx}$ ), but there is a certain pause here before the following prepositional phrase; the better clausula (mentum laudis postulo: type omni debebitur: 9.7\% frequency) therefore deserves preference (cf. also 4.23).

Here D. uses postulabo, against his suggestion, yet cites the manuscript tradition for his use.

3.29: On rhythmical grounds Quirites, albeit better transmitted as the last word of the speech, should be rejected; it is not a sought clausula in itself and must be preceded by a pause, whereas the alternative ending prouidebo yields a trochee + spondee. M. cites as parallel Quirites transmitted as the last word at Red. pop. 1 but commonly emended with Madvig to qua re as a beginning for the following sentence (a solution also adopted by M. in his 1981 edition, a sign of this editor's growing conservatism). tion.

D. chooses to retain Quirites as the last word in spite of his suggested rejec-

4.4: M. prints the transmitted ut comperi legatos Allobrogum ... in Galliam ad suos civis eodemque itinere cum litteris mandatisque ad Catilinam esse missos. The difficulty, as pointed out by H. Nohl (Ciceros Catilinarische Reden, Leipzig-Berlin 1886) is that it later emerges that the letter to Catiline was entrusted to Volturcius, not the Allobroges $(\$ \$ 8,12)$; he accordingly trans- 
posed cum litteris mandatisque to follow immediately upon ad suos civis. M., however, seeks to defend the transmitted text (app. crit. ad loc.) by arguing that it is not expressly said that the letter to Catiline was entrusted to the Gauls; but surely the reader of the transmitted text must connect cum litteris mandatisque with the immediately following ad Catilinam. If one does not want to adopt Nohl's transposition, Ciceronian negligence would appear to be the one possible justification of the transmitted text.

D. does not print the text in question as M. did. However, no explanation accompanies the section in the text as would seem fitting to justify a divergence by omission between texts.

4.8: (of the detention of the captured city conspirators in various communities throughout Italy as proposed by Caesar): ego enim suscipiam et, ut spero, reperiam qui id quod ... statueritis non putet esse suae dignitatis recusare. So runs the transmitted text, printed by M. But this is a decision that will have to be taken in several different communities; Cicero therefore surely means that he will find "the kind of men" who would take that view. Only that will satisfy the requirements of Caesar's plan, and Ernesti's putent strongly commends itself.

D. inserts putent. In his commentary, his explanation is full, providing the student with satisfactory information for the plural verb.

4.11: a much debated passage; transmitted is p.R. (alpha), p.R. exsolvitis (sb, with s iterating $p . R$. afterward), p.R. eripiam i, defendetis gamma. M. adopts Kornitzer's conjecture prohibebo based on the premise that $p . R$. is the remnant of a word beginning with the letters $p r$. If, however, restoration is to begin at the earliest recoverable stage of the transmission and if, as M.'s stemma (p.L) asserts, beta has a direct line to the archetype in this speech, then the reading of its main representatives here ( $\mathrm{sb}$; i's reading looks like a misguided conjecture) deserves greater weight. Clearly its second person ending is a perseverative error from the preceding malueritis, but the verb itself can be retained if changed with Madvig to exsolvet; populus Romanus can then be retained as subject. This also entails omitting, with sb, a before crudelitate, but that is hardly a difficulty given the state of the transmission. It is surprising that M. has not adopted this minimally invasive solution.

D.'s comment here led him to make the change in his own text, where he notes the manuscript difficulties and explains the variances.

As D. did in his review, I have given most space to addressing his "points of disagreement" with M. This is because it seemed most fitting, as D. used M. as a springboard for his Cambridge edition of this text. He did not include extraneous testimonia (criticized in his own review of M.) prior to each speech nor did he needlessly include the extensive collection of later allusions to Cicero's speeches provided in M.'s text. One notable addition is D.'s appendix concerning Cicero's prose rhythm, which, he correctly states, carries over into Cicero's letters. D. presents the dominant research on the subject in this concise and valuable discussion.

In addition to these instances, D. provides an extraordinarily exhaustive study of the Catilinarians, giving attention to numerous standard matters in- 
cluding translation, interpretation of difficult passages, textual matters, grammar, style, syntax, word use, figures, themes, background (especially useful is the presentation of past arguments over certain passages, as in the examples above in which, D. includes past scholars' rendition of the text, sometimes with and others without incorporation, e.g. pp. 99), contemporary evidence, especially from Sallust, and the technical aspects of Latin oratory (e.g. pp. 133, 122, 125). Somewhat annoying are his references to the various texts, as they are complicated and somewhat beyond the student's scholarship unless, of course, for a student of textual study. In sum, the commentary is an excellent and rich corpus of information for any advanced student or scholar.

Concluding the edition, D. proffers comprehensive indices, which include a general index and one to Latin words. There is also a substantial bibliography that I may add is heavily German, not to its discredit. It is complete and essential, as is this new edition, now an indispensable aid to the study of Cicero's $\mathrm{Ca}$ tilinarians, which will be welcomed by both the advanced students and scholars in the field for whom this highly useful edition is intended.

Jaime Claymore

University of Florida claymore@ufl.edu 